03

\title{
История развития методов и интерференционных приборов для измерения малой разности оптических фаз (обзор)
}

\author{
(C) Г.Б. Малыкин \\ Федеральный исследовательский центр Институт прикладной фризики РАН, \\ 603155 Нижний Новгород, Россия \\ e-mail: malykin@ufp.appl.sci-nnov.ru,grig-malykin@yandex.ru
}

Поступила в редакцию 21.09.2020 г.

В окончательной редакции 01.10.2020 г.

Принята к публикации 05.10.2020 г.

\begin{abstract}
Рассмотрены методы интерферометрии, которые применяются для измерения весьма малых разностей фаз в фундаментальных и прикладных задачах. Показано, что первые усовершенствования интерферометрических методов измерения малых разностей фаз для регистрации различных физических явлений во второй половине XIX-начале XX вв. осуществили И.А. Физо, А.А. Майкельсон, Э. Морли, лорд Рэлей, Д.К. Миллер и Ж.М. Саньяк. Показано также, что наиболее чувствительный метод модуляционной интерферометрии был создан в период 1949-1952 гг. советскими радиофизиками А.А. Андроновым, И.Л. Берштейном и Г.С. Гореликом. Отмечено, что метод модуляционной интерферометрии можно было реализовать еще в 1914 г. с помощью фотоэлемента на внешнем фотоэффекте или в 1923 г. с помощью фотоэлемента на внутреннем фотоэффекте (фотодиоде). Однако тогда профессиональные оптики использовали традиционные методы измерения малой разности фаз, а радиофизика как наука только начинала свое становление.

Показано, что методы электрического и фотоэлектрического гармонического анализа, разработанные в конце $\mathrm{XIX-начале} \mathrm{XX} \mathrm{веков} \mathrm{могли} \mathrm{найти} \mathrm{успешное} \mathrm{применение} \mathrm{в} \mathrm{интерферометрии,} \mathrm{но} \mathrm{к} \mathrm{тому} \mathrm{моменту,} \mathrm{когда}$ они могли найти практическое применение, были уже почти полностью забыты.
\end{abstract}

Ключевые слова: интерферометры, разность оптических фаз, фотоприемники.

DOI: 10.21883/OS.2021.02.50555.237-20

\section{1. Введение}

Методы интерферометрии применяются для самых разнообразных целей как фундаментальных, так и прикладных, причем в настоящее время имеется весьма большое число интерферометров различных типов. Наиболее известным является использование многопроходного интерферометра Майкельсона LIGO с длиной плеч $4 \mathrm{~km}$ для регистрации в 2016 г. гравитационных волн от слияния двух черных дыр [1]. Интерферометры различных типов находят весьма широкое применение. Например, это спектральные приборы высокой разрешающей силы для определения диаметров звезд, для эталонного измерения длины волны света. Интерферометры находят широкое применение также в оптикомеханической промышленности.

Настоящая работа посвящена вопросу измерения обусловленных различными физическими явлениями весьма малых разностей фаз и различных интерферометрических методов их измерений и, в частности, наиболее чувствительному модуляционному методу, впервые предложенному И.Л. Берштейном (1908-2000) 70 лет назад [2]. В нашей стране в прошлом был опубликован ряд монографий, посвященных как рассмотрению различных типов интерферометров, так и различным вопросам интерферометрии [3-6], однако только в [6], опубликованной 45 лет назад, модуляционному методу посвящен лишь небольшой параграф. За прошедшее вре- мя опубликовано большое число обзоров и монографий по интерферометрии, однако в них модуляционный метод рассматривается как уже существующий, и не проводится его сравнения с другими методами. Кроме того, в последних обзорах и монографиях рассматривается какой-либо конкретный тип интерферометра. Примером могут служить монографии [7,8], в которых рассмотрен только волоконный кольцевой интерферометр на эффекте Саньяка $[9,10]$ с гармонической фазовой модуляцией, причем в $[7,8]$ не проводится сравнение метода фазовой модуляции с другими методами.

Ниже мы покажем, чем была обусловлена необходимость во введении метода фазовой модуляции в интерферометрию. Будет также показано, что этот метод мог быть создан существенно раньше, чем это произошло в реальности.

\section{2. Ранние методы измерения малой разности фаз}

Первые оптические интерферометры появились в начале XIX века. Это были двухщелевой интерферометр Т. Юнга (1773-1829) [11] и интерферометр [12] О. Френеля (1788-1827), состоящий из двух зеркал, развернутых по отношению друг к другу под весьма малым углом. Эти интерферометры предназначались для демонстрации существования интерференционных полос, 
т. е. для подтверждения волновой природы света, который, согласно воззрениям Т. Юнга и О. Френеля, был проявлением распространения неких механических волн в „светоносном эфире“. Измерений влияния каких-либо физических явлений на сдвиг интерференционных полос в работах $[11,12]$ не проводилось.

Отметим, что в XIX веке и начале XX века измерение сдвига интерференционных полос, обусловленное тем или иным физическим явлением, производилось визуально, при этом точность измерения обычно составляла порядка десятой доли интерференционной полосы. Если освещенность была достаточно высокая и интерференционные полосы не „дрожали“, точность могла составлять 0.05 интерференционной полосы. Поскольку выраженная в размерности набега фазы одна интерференционная полоса составляет $2 \pi \mathrm{rad}$, то, следовательно, точность измерения составляла всего 0.6-0.3 rad. Поэтому оптики-экспериментаторы были вынуждены придумывать методы повышения точности. Простейший метод повышения точности заключался в том, что экспериментатор проводил десятки, а иногда и сотни измерений, а затем проводил усреднение. Это позволяло увеличить точность на порядок, а иногда и несколько больше. Но при наличии некоторой систематической ошибки метод усреднения не мог ее устранить.

\section{Реверсивный метод измерения оптической фазы}

Первым исследованием, в ходе которого оптический интерферометр позволил обнаружить новое физическое явление, были проведенные в 1851 г. эксперименты И.А. Физо (1819-1896) по измерению коэффициента увлечения света в движущейся жидкости [14]. Вид коэффициента увлечения был предложен в 1818 г. О. Френелем [Fresnel1]. И.А. Физо использовал кольцевой интерферометр прямоугольной формы, в двух противоположных плечах которого имелись трубки, через которые протекала вода. Сдвиг вследствие движения воды составлял 0.23 интерференционной полосы [13], т. е. полезный эффект всего в 2.3 раза превышал ошибку. Для повышения точности измерений И.А. Физо менял направление движения воды на противоположное, и в результате суммарный сдвиг составил 0.46 интерференционной полосы [13]. Таким образом, И.А. Физо сумел в два раза увеличить точность измерений и подтвердил теоретические результаты [13]. Отметим, что в большинстве случаев реверсивный метод позволяет устранить систематическую ошибку.

Реверсивный метод в 1913 г. использовал также Ж.М. Саньяк (1869-1928) для регистрации влияния вращения на разность фаз встречных волн в кольцевом интерферометре [15-17]. Это явление получило наименование „эффект Саньяка““ и нашло широкое применение в гироскопии и навигации, а также для обнаружения ряда фундаментальных эффектов $[10,18,19]$. Для того чтобы удвоить точность измерений, Ж.М. Саньяк также менял направление вращения кольцевого интерферометра на противоположное [15-17].

\section{Метод многолучевой интерферометрии}

В 1896 г. лорд Рэлей (Дж.У. Стрэтт, 1842-1919) для измерения показателей преломления газообразных аргона и гелия (которые очень малы) применил метод двулучевой интерферометрии [20]. В двулучевом интерферометре Рэлея пучок света с помощью специальной диафрагмы расщепляется на два пучка, которые проходят через оптическую среду и затем снова соединяются. В двулучевых интерферометрах освещенность вдоль интерференционных полос меняется по синусоидальному закону. Для двулучевых голограмм требуются фотоматериалы с высоким пространственным разрешением.

Отметим, что существует термин „однолучевая интерферометрия“, который является не вполне корректным и даже жаргонным, но в последнее время употребляется в научной литературе $[21,22]$. Разумеется, в интерференции всегда участвуют, как минимум, два луча. Указанный не вполне корректный термин пришел в интерферометрию из голографии, а точнее говоря, из-за не вполне точного определения методов восстановления первичных изображений из голограмм. Например, в схеме Габора опорный источник и предмет расположены на оси голограммы. Осевые голограммы иногда называют также однолучевыми, так как используется один пучок света, часть которого рассеивается предметом и образует предметную волну, а другая часть, прошедшая через объект без искажения, - опорную волну. При этом все три волны распространяются в одном и том же направлении, создавая взаимные помехи. В частности, в схеме Лейта и Упатниекса $[23,24]$, которую также иногда именуют однолучевой $[21,22]$ (она подробно рассмотрена в $[25,26]$ ), такие помехи устраняются наклоном опорной волны (неосевая схема). Некорректный термин „однолучевой

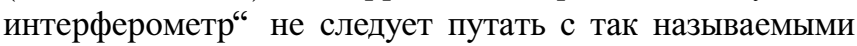
однопроходными интерферометрами, которые реально существуют и, в частности, находят применение для измерения рельефа поверхности с помощью интерферометрического однопозиционного комплекса дистанционного зондирования Земли, реализованного в виде авиационного радиолокатора с синтезируемой апертурой антенны [27].

В [6] рассмотрен трехлучевой интерферометр Рэлея, который позволяет измерять сдвиг фазы $0.025 \mathrm{rad}$. Интерферометр Рэлея не потерял свое значение, например, его применению в молекулярной спектроскопии посвящена диссертация [28].

В трехлучевом интерферометре [29] применена более сложная оптическая схема, и, как показано в [6], его чувствительность составляет $0.02 \mathrm{rad}$. Сложность применения интерферометра [29] заключается в том, что для достижения указанной точности требуется последовательное проведение измерений на нескольких длинах волн. В трехлучевом интерферометре Ф. Цернике 
(1888-1966) [30-32] измерения можно было проводить существенно проще, чем в [29], а погрешность измерения составляет $0.025 \mathrm{rad}$.

Существуют четырехлучевые интерферометры $[33,34]$. В четырехлучевом интерферометре [34] чувствительность составляет $0.01 \mathrm{rad}$. В обзоре [35,36] рассмотрено применение интерференционных фильтров в многолучевых интерферометрах. В работе [37] рассмотрена многолучевая двухчастотная интерферометрия. Многолучевые интерферометры не позволяют достичь очень высокой точности измерения малой разности фаз. Как будет показано ниже, в разд. 3, они иногда применяются совместно с другими методами, что приводит к хорошему результату.

\section{Метод вспомогательного оптического контура}

Реверсивный метод измерения оптической фазы не всегда можно реализовать. Можно изменить направление движения жидкости или направление вращения оптического стола. Но как быть, если измеряется угловая скорость вращения Земли? В 1925 г. профессор университета Чикаго А.А. Майкельсон (1852-1931) с соавторами осуществил эксперименты по измерению угловой скорости вращения Земли с помощью кольцевого интерферометра размером приблизительно $620 \times 340 \mathrm{~m}$ [38]. Такая большая площадь кольцевого интерферометра потребовалась потому, что угловая скорость вращения Земли составляет всего $\simeq 2 \cdot 10^{-6} \mathrm{rad} / \mathrm{s}$. Если бы измерение проводилось с помощью миниатюрного кольцевого интерферометра, то его можно было бы просто перевернуть на поверхности оптического стола и тем самым реализовать реверсивный метод. Однако перевернуть кольцевой интерферометр [38], представляющий собой расположенный на поверхности Земли прямоугольный контур из водопроводных труб диаметром $300 \mathrm{~mm}$, из которых был откачан воздух, было невозможно.

Но главная проблема эксперимента [38] состояла в отсутствии начала отсчета: поскольку вращение Земли остановить невозможно, то непонятно было, где должен был быть „ноль“ интерференционных полос. А.А. Майкельсон нашел оригинальное решение этой проблемы: был создан вспомогательный кольцевой оптический контур малой площади, так что вращение Земли не вызывало в нем практически никакого сдвига интерференционных полос [38]. Таким образом, имелись две интерференционные картины - от малого и от большого контуров, при этом отсчет велся от „нуля“ первой интерференционные картины. Всего было проведено 269 измерений, и усредненный результат составил $0.23 \pm 0.05$ интерференционной полосы, что хорошо согласовалось с теоретическим расчетом $(0.236 \pm 0.02)$ [38]. Отметим, что отдельные замеры в [38] имели очень большой разброс, а среднеквадратичное отклонение было $\sim 50 \%$ от средней величины.

\section{Метод компенсации}

Метод компенсации заключается в том, что на определенную точку конструкции интерферометра устанавливается некоторый эталонный груз, который незначительно прогибает конструкцию и смещает интерференционную картину на одну полосу. Тогда, если под воздействием каких-либо эффектов интерференционная картина смещается на некоторую долю полосы, можно подобрать груз, который вернет полосы в исходное состояние. Отношение веса этого груза к эталонному и дает значение смещения интерференционной картины. Метод компенсации удобно применять в тех случаях, когда измеряемый эффект не меняется во времени. Например, это могут быть измерения, повторяющие эксперимент И.А. Физо [13]. Но если измеряемый эффект меняется во времени, например в ходе экспериментов Майкельсона-Морли [39,40], когда интерферометр Майкельсона медленно вращается, метод компенсации может быть использован только для калибровки чувствительности интерферометра. При применении метода компенсации для экспериментов типа Майкельсона-Морли $[39,40]$ необходимо останавливать интерферометр Майкельсона при каждом отсчете.

Еще в 1905 г. профессора университета Вестерн Резерв города Кливленд Э. Морли $(1838-1923)$ и Д.К. Миллер (1866-1941) в ходе повторений экспериментов Майкельсона-Морли [39,40] выяснили, что груз, помещенный на одном из концов крестообразного основания интерферометра Майкельсона, приводит к вполне определенному сдвигу интерференционные картины [41]. В 1926-1927 гг. в работах $[42,43]$ небольшой груз (порядка 5-7.5g), устанавливаемый на мраморную плиту, на которой располагался интерферометр Майкельсона, приводил к сдвигу на интерференционную полосу. В работах $[42,43]$ метод компенсации использовался для прецизионных измерений.

\section{3. Развитие методов измерения малой разности фаз}

Дальнейший прогресс в развитии методов измерения малой разности фаз произошел во второй половине 20-х гг. прошлого века.

\section{Метод ступенчатого зеркала}

В 1926 г. почетный государственный стипендиат в области физики Р.Дж. Кеннеди $(1897-1986)$ для повышения точности измерений в ходе повторений экспериментов Майкельсона-Морли [39,40] предложил и реализовал в Калифорнийском технологическом институте метод ступенчатого зеркала [42]. В работе [42] при вакуумном напылении платины на плоскую стеклянную подложку на поверхности зеркала (которое предназначалось для расположения в одном из плеч интерферометра Майкельсона) делалась „ступенька“ толщиной $0.05 \lambda$, 
где $\lambda=0.5461 \mu \mathrm{m}$ - длина волны света. По оценкам [42] чувствительность измерений должна была составить $5 \cdot 10^{-5}$ интерференционной полосы, однако реальная чувствительность в экспериментах [42] была $10^{-3}$ интерференционной полосы $\left(\sim 6 \cdot 10^{-3} \mathrm{rad}\right)$. В ходе измерений [42] интерферометр Майкельсона не вращался, а поворачивался на некоторый угол и останавливался, после чего можно было микрометрическим винтом сдвигать зеркало вперед или назад до того положения, когда освещенности интерференционных полос от основной части зеркала и от ступеньки не сравняются. Затем по расстоянию, на которое сдвинулось зеркало, вычислялся сдвиг интерференционных полос под влиянием измеряемого эффекта - в данном случае, как и в экспериментах Майкельсона-Морли $[39,40]$, исследовалось влияние гипотетического „эфирного ветра“. Однако сдвигать зеркало было не вполне удобно, поскольку при этом происходили весьма незначительные перекосы, которые приводили к расстройке интерференционной картины. Кроме того, сдвиги зеркала были настолько малы, что их было трудно отсчитывать. Поэтому Р.Дж. Кеннеди применил метод компенсации: небольшой груз, устанавливаемый на мраморную плиту, на которой располагался интерферометр Майкельсона, приводил к сдвигу на интерференционную полосу. Затем при каждом угловом положении интерферометра Майкельсона на ту же точку плиты устанавливался меньший груз, который подбирался так, чтобы освещенности интерференционных полос от основной части зеркала и от ступеньки сравнялись. По соотношению весов первого и второго груза и вычислялась величина эквивалентного сдвига зеркала.

Метод ступенчатого зеркала высоко оценил С.И. Вавилов (1891-1951), который опубликовал в журнале УФН сокращенный перевод работы Р.Дж. Кеннеди [42-44], а позднее описал эксперименты [42] в своей известной монографии [45].

В 1927 г. в том же Калифорнийском технологическом институте К.К. Иллингворт использовал интерферометр [42] и несколько его усовершенствовал, в результате чего получил чувствительность $\sim 4 \cdot 10^{-3} \mathrm{rad}[43]$. Отметим здесь, что так же, как и в экспериментах Майкельсона-Морли $[39,40]$, в экспериментах Р.Дж. Кеннеди [42] и К.К. Иллингворта [43] „эфирный ветер“, разумеется, не был обнаружен.

Еще раз подчеркнем, для повышения точности измерений Р.Дж. Кеннеди [42] и К.К. Иллингворт [43] использовали и метод ступенчатого зеркала, и метод компенсации. Только совместное применение этих двух методов позволило увеличить точность измерения по сравнению с лучшими многолучевыми методами в 2-2.5 раза.

\section{Стробоскопический метод}

В 1928 г. в Национальной физической лаборатории Великобритании (Лондон) исследовали колебания тонкой зеркальной стеклянной пластинки, прикрепленной к мембране телефона [46]. Совместно со вторым неподвижным зеркалом эта пластинка составляла интерферометр Фабри-Перо, длина которого модулировалась по гармоническому закону с амплитудой $\lambda / 4$ (где $\lambda$ - длина волны света источника излучения) и частотой $\sim 1 \mathrm{kHz}$. Интерференционная картина наблюдалась визуально с помощью вспомогательной призмы. В случае непрерывного освещения интерференционные полосы размывались вследствие колебаний одного из зеркал интерферометра Фабри-Перо. Для освещения применялась ртутная лампа со светофильтром, которая генерировала последовательность коротких вспышек с частотой колебания зеркала. Длина волны света $\lambda=0.5461 \mu \mathrm{m}$. В этом случае интерференционные полосы наблюдались как неподвижные, и можно было точно измерить амплитуду колебаний зеркала. В работе [47], выполненной в 1928 г. в Кёльне (Германия), использовалась та же оптическая схема, что и в [46]. В СССР стробоскопический метод впервые применялся в 1937 г. [48] для оптической схемы сдвоенного интерферометра Майкельсона. В [48] в качестве источника излучения использовалась обычная лампа накаливания с обтюратором в виде диска с узкой щелью, который создавал прерывистое излучение. Отметим, что в рассмотренных работах [46-48] использовались многопроходные интерферометры (разд. 2).

В настоящее время существуют сотни, если не тысячи работ, посвященных стробоскопическому методу в интерферометрии. Особенно широкое применение стробоскопический метод получил в голографической интерферометрии [25] (см. также обзор [49]) и, в частности, в цифровой голографической интерферометрии [50]. Следует отметить, что в случае, когда скорость движения произвольного объекта велика, а размеры его достаточно велики для того, чтобы сверхкороткие импульсы света достигали различных участков поверхности объекта в различные моменты времени, возникает ряд искажающих эффектов, связанных с явлением запаздывания света, которые необходимо учитывать при обработке результатов измерений [51]. Можно указать на соответствующие эксперименты [52-56], в которых проводились съемки голограмм быстро вращающихся лопастей вентилятора. Специфика голографического изображения, как впрочем и любой интерференционной картины, такова, что за отображение крупных деталей объекта отвечают самые узкие интерференционные полосы. Вследствие этого для адекватного восстановления изображения объекта, в данном случае лопастей вентилятора, приходилось учитывать конечность скорости света [51,53], эффект релятивистской аберрации [51] и релятивистское сокращение длины движущегося тела, а также поперечный эффект Допплера [51,54-56].

Стробоскопический метод в интерферометрии в определенном смысле является предшественником модуляционного метода: длина одного из плеч интерферометра модулируется по гармоническому закону. Но в отличие 
от модуляционного метода в данном случае измеряется не изменение малой разности фаз, а только амплитуда колебаний длины интерферометра (или одного из его плеч).

\section{4. Модуляционный метод измерения малой разности фаз}

\section{Модуляционный метод Р. Дикке}

Первым модуляционный метод для измерения температуры фонового микроволнового излучения в 1946 г. в Массачусетском технологическом институте применил Р. Дикке (1916-1997) [57]. Следует подчеркнуть, что в работе [57] не проводилось измерение изменения малой разности фаз, это были чисто амплитудные измерения. В модуляционным радиометре Дикке антенна и эталонная нагрузка попеременно на равные промежутки времени подключаются ко входу приемника с помощью электронного, ферритового или механического переключателя (модулятора). В [57] была реализована чувствительность $10^{-16} \mathrm{~W}$ (можно было измерять изменение температуры фонового микроволнового излучения с точностью $0.23 \mathrm{grad}$ ). В работе [58] было показано, что в [57] точность измерения была ошибочно завышена в 2 раза.

Первое измерение малой разности фаз с помощью модуляционного метода в саньяковской интерферометрии. Модуляционный метод измерения малой разности фаз был впервые предложен и реализован в саньяковской интерферометрии (гироскопии на эффекте Саньяка) в 1950 г. И.Л. Берштейном [2] в Горьковском физикотехническом институте (ГИФТИ) при Горьковском государственном университете (ГГУ) [18,59]. Модуляционный метод измерения малой разности фаз [2] появился в определенном смысле как побочный продукт большого цикла работ И.Л. Берштейна по теоретическому и экспериментальному исследованию частотных и амплитудных флуктуаций лампового генератора гармонических колебаний [59]. Его работа [60] была удостоена премии им. Л.И. Мандельштама, которую ему на заседании АН СССР вручил С.И. Вавилов. Тем не менее результаты работы [60] были известны только среди советских и зарубежных радиофизиков. Академик А.А. Андронов (1901-1952), в прошлом научный руководитель кандидатской диссертации И.Л. Берштейна [61], предложил ему найти яркий, перспективный и в то же время весьма слабый физический эффект, регистрация которого могла бы привлечь внимание широкого физического сообщества к уникальным возможностям метода [60]. Вместе они пришли к выводу, что следует зарегистрировать эффект Саньяка в диапазоне радиоволн, на длине волны $\lambda=10 \mathrm{~m}$ (частота $30 \mathrm{MHz}$ ). Сложность задачи заключалась в том, что при прочих равных условиях (угловая скорость вращения, площадь кольцевого интерферометра) на длине волны $\lambda=10 \mathrm{~m}$ обусловленная эффектом Саньяка разность фаз встречных волн в кольцевом интерферометре приблизительно в $2 \cdot 10^{7}$ раз меньше, чем в оптическом диапазоне. Контур кольцевого интерферометра [2] состоял из многовитковой катушки радиокабеля диаметром $2 \mathrm{~m}$ и длиной $244 \mathrm{~m}$, диэлектрическая постоянная радиокабеля составляла $\varepsilon=2.24$ (эквивалентный показатель преломления $n=\sqrt{\varepsilon} \simeq 1.5$ ). Измерения проводились в цокольном помещении ГИФТИ, угловая скорость вращения составляла $1-1.3 \mathrm{rps}$. Ожидаемая саньяковская разность фаз составляла всего $10^{-5} \mathrm{rad}$. Эксперименты И.Л. Берштейна активно поддержали А.А. Андронов и зав. отделом ГИФТИ, в котором работал И.Л. Берштейн, профессор Г.С. Горелик (1905-1957). Чтобы обнаружить столь малую разность фаз, требовался фазовый модулятор. К счастью, еще в 1946 г. Г.С. Горелик поручил И.Л. Берштейну разработку радиометра по типу радиометра Дикке [57], который и был изготовлен в 1948 г. [59,62]. Таким образом, И.Л. Берштейн хорошо знал метод Р. Дикке [57].

Для измерения разности фаз встречных волн в кольцевом интерферометре в [2] был применен оригинальный метод модуляции, отчасти сходный с методом Р. Дикке [57]. Излучение встречных волн интерферировало не между собой, а поочередно с опорным сигналом, идущим непосредственно от генератора частоты $30 \mathrm{MHz}$. Коммутация осуществлялась с помощью двух электромеханических реле с частотой $12.5 \mathrm{~Hz}$, в результате чего в выходном сигнале возникала амплитудная модуляция на этой же частоте. Затем сигнал с частотой $12.5 \mathrm{~Hz}$ усиливался и подавался на синхронный детектор. В результате работы [2] удалось зарегистрировать эффект Саньяка, а также показать, что его величина не зависит от диэлектрической проницаемости радиокабеля (т.е. от показателя преломления оптической среды). Более подробное рассмотрение экспериментов [2] приводится во 2-й части докторской диссертации И.Л. Берштейна [63].

\section{Метод измерения малой разности оптических фаз с помощью гармонической модуляции фазы}

В работе И.Л. Берштейна [2] измерения проводились не в оптическом, а в радиодиапазоне электромагнитных волн. Кроме того, в [2] использовалась не модуляция фазы в интерферометре по гармоническому закону, а попеременная коммутация встречных волн с генератором синусоидальных колебаний по принципу, близкому к методу Р. Дикке [57]. В 1952 г. Г.С. Горелик предложил использовать гармоническую модуляцию фазы в интерферометре с последующим усилением сигнала амплитудной модуляции с выхода фотоприемника с помощью узкополосного усилителя, настроенного на частоту модуляции [64]. Г.С. Горелик и соавторы также провели эксперимент, в ходе которого зеркало в одном из плеч интерферометра Майкельсона $(\lambda=0.4358 \mu \mathrm{m})$ было приклеено к мембране телефона, на который 
подавалось синусоидальное напряжение звуковой частоты [65]. В качестве фотоприемника использовался фотоэлектронный умножитель (ФЭУ). Оптимальной была амплитуда модуляции длины плеча интерферометра Майкельсона $1.85 \lambda /(2 \pi)$. При этом амплитуда модуляции фазы составляла $1.85 \mathrm{rad}$, чему соответствует максимум функции Бесселя первого рода первого порядка. Точность измерения в [65] составила $1.4 \cdot 10^{-3} \mathrm{rad}$.

Почти сразу после $[64,65]$ был опубликован обзор Г.В Розенберга (1914-1982) [66], в котором он отметил, что минимально обнаруживаемая величина сдвига интерференционных полос при использовании модуляционного метода может составлять $10^{-6} \lambda\left(\simeq 6 \cdot 10^{-6} \mathrm{rad}\right)$ и даже менее. В дополнении к обзору [66] И.Л. Берштейн указал, что эта минимально обнаруживаемая величина может составлять $5 \cdot 10^{-7} \lambda\left(\simeq 3 \cdot 10^{-6} \mathrm{rad}\right)$ [67]. Эксперименты И.Л. Берштейна $[68,69]$ подтвердили результаты теоретических оценок [67]. В настоящее время при использовании лазерных источников излучения и высокочувствительных фотоприемников точность измерения малых изменений разности фаз с помощью модуляционного метода достигает $10^{-6}-10^{-7} \mathrm{rad}$.

Отметим, что из $[64,65]$ становится ясно, почему И.Л. Берштейн в [2] не мог реализовать модуляцию фазы по синусоидальному закону. Для оптимальной фазовой модуляции с амплитудой $1.85 \mathrm{rad}$ на длине волны $\lambda=10 \mathrm{~m}$ кабеля с диэлектрической постоянной $\varepsilon=2.24$ пришлось бы периодически менять длину кабеля приблизительно на $2 \mathrm{~m}$, что практически невозможно. Поэтому в [2] был применен метод модуляции, сходный с методом Р. Дикке [57].

Для измерения малых изменений разности фаз под воздействием некоторого физического эффекта с помощью модуляционного метода можно использовать ряд методик. Например, можно с помощью подбора постоянной разности фаз в плечах интерферометра (это можно сделать, подавая постоянное напряжение на электромагнитный телефон или на пьезоэлемент, к которому приклеено подвижное зеркало интерферометра) установить интерференцию на крутой участок интерференционной картины, который находится точно посередине между максимумом и минимумом интерференционной картины. Тогда незначительные изменения разности фаз в плечах интерферометра приведут к изменению модуляции амплитуды интенсивности фототока на выходе фотоприемника на первой гармонике частоты модуляции длины интерферометра. После этого можно незначительно изменить постоянное напряжение на телефоне или пьезоэлементе так, чтобы амплитуда первой гармоники частоты модуляции вновь стала максимальной. Зная величину постоянного напряжения, сдвигающего интерференционную картину на одну полосу, можно вычислить сдвиг фазы от измеряемого эффекта. Существует и другая методика: с помощью подбора постоянной разности фаз в плечах интерферометра следует установить интерференцию точно на максимум или минимум интер- ференционной картины. Тогда модуляция амплитуды интенсивности фототока на выходе фотоприемника на первой гармонике частоты модуляции будет равна нулю (при этом модуляция амплитуды будет иметь место на второй и более высоких четных гармониках частоты модуляции). Незначительные изменения разности фаз в плечах интерферометра приведут к появлению модуляции небольшой амплитуды интенсивности фототока на первой гармонике частоты модуляции. После этого можно незначительно изменить постоянное напряжение на телефоне или пьезоэлементе так, чтобы модуляция амплитуды первой гармоники частоты модуляции вновь стала равна нулю. Далее, как и в предыдущем случае, по соотношению этого напряжения к напряжению, сдвигающему интерференционную картину на одну полосу, можно вычислить сдвиг фазы от измеряемого эффекта.

Частоту фазовой модуляции $F$ обычно выбирают так, чтобы она несколько превышала $1 \mathrm{kHz}$, поскольку на этой частоте почти полностью спадают так называемые фликкерные шумы входного усилителя, спектральная плотность которых пропорциональна $\sim F^{-1}$. В некоторых случаях выбирают $F \geqslant 10 \mathrm{kHz}$.

В 1950 г. Г.С. Горелик опубликовал весьма полезный учебный курс [70], который в 1950-1952 гг. был подвергнут несправедливой критике, перешедшей в откровенную травлю автора в ГГУ [71]. В июне 1953 г. он был по конкурсу избран профессором, зав. кафедрой общей физики в МФТИ, а вскоре и деканом радиофизического факультета МФТИ [72]. В декабре 1953 г. он был назначен заведующим организованной им лаборатории статистической радиофизики ИРЭ АН СССР [72], но в июне 1957 г. трагически погиб в г. Долгопрудном [72]. После отъезда Г.С. Горелика в Москву ту часть его отдела, которая занималась измерением частотных и амплитудных флуктуаций генераторов радио и СВЧ диапазонов, возглавил И.Л. Берштейн, который практически до конца своих дней занимался данной тематикой. После создания лазеров эти исследования перешли в оптическую область. Так, в 1967-1968 гг. ученики И.Л. Берштейна Ю.И. Зайцев (1933-1989) и Д.П. Степанов (1933-2001) сумели перенести его метод гетеродинирования [60] из радиодиапазона в оптический диапазон и измерили ширину естественной линии излучения гелий-неонового лазера $(\mathrm{He}-\mathrm{Ne}$ лазер, $\lambda=0.63 \mu \mathrm{m})$ [73,74]. В 1983 г. ученики Ю.И. Зайцева В.М. Геликонов (р. 1943 г.) и Г.Б. Малыкин (р. 1948 г.) обнаружили существенное снижение ширины естественной линии излучения гелий-неонового лазера с нелинейно поглощающей метановой ячейкой $\left(\mathrm{He}-\mathrm{Ne} / \mathrm{CH}_{4}\right.$-лазер, $\left.\lambda=3.39 \mu \mathrm{m}\right)$ [75], что связано с эффектом автостабилизации частоты в газовом лазере c нелинейно поглощающей ячейкой [76]. В 1998 г. В.М. Геликонов разработал Не-Ne-лазер $(\lambda=0.63 \mu \mathrm{m})$, в котором при селекции продольных типов колебаний c использованием поглощающей пленки в узле моды получена широкая область одночастотной генерации 
$(2 \mathrm{GHz})$ [77]. По измерениям естественных флуктуаций частоты излучения такого лазера при превышении порога генерации в 2.7 раза и уровне выходной мощности $1 \mathrm{~mW}$ определено значение естественной компоненты ширины линии на уровне $0.001 \mathrm{~Hz}$. С использованием достигнутого уровня монохроматичности в [77] были проведены измерения сверхмалых колебательных перемещений на уровне десятков наноангстрем $\left(8 \cdot 10^{-18} \mathrm{~m}\right)$, что соответствует относительному изменению длины резонатора порядка $6 \cdot 10^{-18}$. Теоретическими и экспериментальными исследованиями в этой области и по сей день занимаются ученики учеников И.Л. Берштейна.

Невозможно в рамках данного обзора перечислить все работы И.Л. Берштейна и его школы по данной теме (ссылки на большинство работ самого И.Л. Берштейна приводятся в [59]). Здесь укажем лишь на последнюю его журнальную публикацию [78], в которой было проведено исследование работы автокомпенсационной схемы регистрации сигнала вращения на выходе волоконного кольцевого интерферометра (ВКИ), работа которой основана на фазовой модуляции на двух, весьма различных частотах. Схема [78] позволяет исключить зависимость выходного сигнала ВКИ от изменений интенсивности источника излучения.

Отметим, что если интенсивность света источника излучения достаточно велика, а шумы входного усилителя существенно меньше дробовых шумов фототока, то минимальный уровень измерения разности фаз в интерферометре с помощью модуляционного метода лимитируется уровнем дробовых шумов фототока $[2,64,65,67]$. Минимальный уровень измерения разности фаз в интерферометре лимитируется уровнем дробовых шумов не только в оптическом диапазоне, но и в других диапазонах электромагнитного излучения, например в радиодиапазоне [2].

\section{Особенности применения метода гармонической модуляции фазы в кольцевых интерферометрах}

В подавляющем большинстве типов интерферометров имеется возможность модулировать длину одного из плеч, при этом длина другого плеча остается неизменной. Поэтому частота гармонической модуляции в принципе может быть сколь угодно низкой. Но в кольцевом интерферометре, модулируя длину кольца, мы одновременно меняем длину оптического пути для обеих встречных волн. Особенно остро этот вопрос встал после создания в 1976 г. волоконных кольцевых интерферометров - высокочувствительных датчиков угловой скорости вращения $[7,8,10]$. Широкое практическое применение нашел метод несимметричной фазовой модуляции [79,80], когда фазовый модулятор расположен на одном из концов контура ВКИ. Как правило, фазовый модулятор представляет собой отрезок длиной $1-3 \mathrm{~m}$ одномодового волоконного световода (ОВС), намотанного на пьезоцилиндр или приклеенного к пьезошайбе, с приложенным гармоническим напряжением частоты $F$ с амплитудой в несколько вольт. Излучение встречных волн в контуре ВКИ проходит фазовый модулятор, когда он имеет различную оптическую длину. В этом случае в фототоке имеется амплитудная модуляция: присутствует сумма гармоник частоты фазовой модуляции [81]. При отсутствии вращения в выходном фототоке присутствуют только четные гармоники, а при наличии вращения (или любого другого невзаимного эффекта) появляются также и нечетные гармоники частоты фазовой модуляции. При измерении скорости вращения, как правило, используют сигнал на первой гармонике частоты фазовой модуляции $F$.

В работах $[81,82]$ было показано, что наличие модуляции интенсивности излучения на второй гармонике частоты [81] или присутствие в фазовой модуляции второй гармоники частоты $F[82]$ приводит к сдвигу нуля ВКИ. В нашей работе [83] было показано, что не только вторая, но и любая четная гармоника частоты $F$ приводит к сдвигу нуля ВКИ, но при условии $F \simeq c /(2 L n)$ (где $L-$ длина контура ВКИ, $n \sim 1.5$ - эффективный показатель преломления ОВС, из которого изготовлен контур ВКИ, на средней длине волны источника излучения $\lambda_{0}, c-$ скорость света в вакууме) основной вклад в сдвиг нуля вносит вторая гармоника. Отметим, что в ВКИ частота фазовой модуляции существенно больше, чем в интерферометрах других типов. Из вышеуказанного условия следует, что при длине контура ВКИ $500 \mathrm{~m}$ оптимальная частота фазовой модуляции составляет $F=200 \mathrm{kHz}$, а при длине контура ВКИ $200 \mathrm{~m}-F=500 \mathrm{kHz}$. Отметим, что в работе И.Л. Берштейна [2] оптимальная частота фазовой модуляции должна была составлять $F \sim 250 \mathrm{kHz}$, но в реальности электромеханические реле осуществляли коммутацию с частотой всего $12.5 \mathrm{~Hz}$. Для повышения частоты фазовой модуляции до $1 \mathrm{kHz}$ И.Л. Берштейн также применил электронный коммутатор на четырех радиолампах [63], однако не добился увеличения чувствительности к вращению.

В [83] также было показано, что паразитная амплитудная модуляция в выходном сигнале на частоте $F$, вызванная наличием частоты $2 F$ в обусловленном вращением ВКИ сигнале фазовой модуляции, имеет как синфазную, так и квадратурную составляющие по отношению к полезному сигналу на частоте $F$. Рассматриваемый эффект приводит к сдвигу нуля ВКИ, который в отличие от поляризационной невзаимности $(П Н)$ не зависит от наличия поляризатора или деполяризатора в схеме ВКИ. В работе [84] было показано, что в некоторых случаях полезно измерять угловую скорость вращения ВКИ не по первой, а по третьей или пятой гармоникам частоты $F$ в сигнале амплитудной модуляции. В работе [85] рассчитаны величины полезного сигнала, а также синфазной и квадратурной компонент паразитной модуляции, вызванных второй гармоникой паразитной фазовой модуляции. В [85] показано, что 
при обработке сигнала с выхода ВКИ по третьей или пятой гармоникам частоты фазовой модуляции величины синфазной и квадратурной компонент паразитной модуляции в некотором диапазоне изменения амплитуды фазовой модуляции практически не зависят от амплитуды фазовой модуляции.

Модуляция интенсивности излучения в ВКИ может возникнуть как в самом источнике излучения, так и вследствие модуляции потерь света в фазовом модуляторе из-за модуляции радиуса намотки ОВС [86,87].

Известно, что при значениях напряжения порядка сотен вольт на миллиметр пьезокерамика нелинейно преобразует электрическое напряжение в механическое смещение [88]. В этом случае имеет место различие модуля упругости пьезокерамики для сжатия и растяжения $[88,90]$, что вызывает квадратичную нелинейность характеристики пьезопреобразователя. В случае подачи синусоидального напряжения это приводит к появлению четных гармоник основной частоты. Отметим, что к таким же последствиям приводит также наличие небольших пузырьков воздуха в покрытии намотанного на пьезоциллиндр ОВС [91]. Из развитой в работах [92,93] теории нелинейных сред с зернистой структурой, к которым в принципе может быть отнесена пьезокерамика, следует, что при наличии неидеальной упаковки доменов заметная разномодульность может возникнуть и при очень низких по сравнению с вышеуказанными напряжениях, когда деформации составляют $10^{-8}-10^{-7}$ от размера образца.

Однако наши экспериментальные исследования показали [94], что при сравнительно небольших напряжениях синусоидальной формы на пьезопреобразователе и соответственно малых деформациях он практически линейно преобразует электрическое напряжение в механическое смещение и не приводит к возникновению обнаруживаемого на фоне шумов аппаратуры уровня второй гармоники. Можно сделать вывод, что, хотя пьезокерамика ЦТС-19 является зернистой средой, ее домены достаточно плотно упакованы и не проявляют заметных нелинейных свойств при малых смещениях, т. е. при малых деформациях пьезокерамика не проявляет заметных разномодульных свойств. Следовательно, вторая гармоника частоты фазовой модуляции главным образом является следствием неидеальной работы генератора синусоидального напряжения, который возбуждает пьезопреобразователь фазового модулятора ВКИ.

Отметим, что в некоторых случаях в ВКИ применяется не гармоническая фазовая модуляция, а периодическая модуляция другой формы $[95,96]$. Так называемая автокомпенсационная схема регистрации сигнала вращения ВКИ, работа которой основана на фазовой модуляции на двух, весьма различных частотах [78], рассмотрена выше.

\section{5. Методы гармонического анализа интерферометрического сигнала}

Модуляционный метод измерения малой разности фаз предполагает гармонический анализ сигнала с нагрузки фотоприемника на выходе интерферометра. На протяжении долгого времени этот анализ осуществлялся с помощью узкополосных (резонансных) усилителей, настроенных на частоту фазовой модуляции, или с помощью так называемого синхронного детектирования. Последний метод в ряде случаев предпочтителен, поскольку позволяет реализовать более узкую полосу пропускания. Этот метод заключается в подаче на одну из обмоток высокочастотного трансформатора сигнала с нагрузки фотоприемника, а на другую обмотку опорного сигнала, т.е. напряжения с генератора синусоидальных колебаний, который осуществляет фазовую модуляцию. После этого осуществляется обычное детектирование напряжения с выхода высокочастотного трансформатора.

Если физическое явление, приводящее к возникновению малой разности фаз на выходе интерферометра, не меняется во времени, то на выходе узкополосного усилителя или синхронного детектора имеет место постоянное напряжение, которое пропорционально величине измеряемого явления. Если величина физического явления меняется во времени, то соответствующим образом меняется и напряжение на выходе узкополосного усилителя или синхронного детектора. В этом случае полоса пропускания узкополосного усилителя или синхронного детектора должна быть достаточно большой, чтобы не исказить переменный во времени сигнал. Особым случаем является гармоническое изменение во времени малой разности фаз на выходе интерферометра, что, например, имеет место в ходе экспериментов Майкельсона-Морли $[39,40]$ и их повторений, когда интерферометр Майкельсона медленно вращается. При этом могут возникать как первая, так в принципе и более высокие гармоники частоты вращения.

В настоящее время использование узкополосных усилителей и синхронных детекторов для измерения малой разности фаз почти не применяется, поскольку это аналоговые методы. Теперь сигнал с нагрузки фотоприемника на выходе интерферометра оцифровывается и затем с помощью специальных программ производится вычисление его временной зависимости и фурье-анализ.

Любопытно отметить, что фактически оцифровка сигнала, разности фаз на выходе интерферометра, осуществлялась еще в XIX веке. Экспериментатор записывал фазовый сдвиг на выходе интерферометра того или иного типа через некоторые промежутки времени. Никакого другого метода регистрации разности фаз в плечах интерферометра тогда еще не существовало. В частности, это имело место в ходе экспериментов Майкельсона-Морли [39,40] и их повторений $[42,43,97-103]$. Но еще в начале $\mathrm{XX}$ века такая „оцифровка“ широко применялась [42,43,97-103], хотя уже существовал более 
прогрессивный и точный метод регистрации разности фаз в плечах интерферометра с помощью фотопленки $[15,15,16,104,105]$.

Первым гармонический анализ (фурье-анализ) своих результатов по повторению экспериментов Майкельсона-Морли [39,40] осуществил Д.К. Миллер (1866-1941, о нем [106-108]) в начале 30-х гг. XX века [109]. Сами эксперименты Д.К. Миллера проводились в 20-е гг. XX века [97-101], а их регистрация осуществлялась с помощью „оцифровки“ поворота интерферометра Майкельсона, который совершал один оборот за 50 s, с шагом 22.5 углового градуса. Д.К. Миллер в [109] проводил фурье-анализ следующим образом. На миллиметровую бумагу в определенном масштабе по осям абцисс и ординат расставлялись точки, соответствующие результатам „оцифровки“: по оси абцисс - угол поворота интерферометра Майкельсона, по оси ординат разность фаз в плечах интерферометра. Затем по этой кривой прокатывалось колесико, связанное специальным устройством с механическим анализатором спектра. Такой анализатор существенно упрощал фурье-анализ различных кривых по сравнению с ручным расчетным методом [110]. Д.К. Миллер использовал созданный в 1894 г. механический анализатор спектра О. Генрици (1840-1918, английский математик) [111], который мог вычислять от трех до пяти гармоник основной частоты и состоял из рычажных передач, вала, большого числа колес, шестеренок и трех или пяти шаров (по числу регистрируемых гармоник), которые могли вращаться вокруг своих ортогональных осей [110].

Следует отметить, что наиболее совершенный механический анализатор спектра, позволяющий вычислять 80 гармоник, создали А.А. Майкельсон и С.В. Стрэттон (1861-1931), создатель и первый директор Национального бюро стандартов США (1901-1922, о нем [112]) [113,114].

Д.К. Миллер по первой своей научной специализации был ведущим акустиком США, и при его консультациях проходило производство музыкальных инструментов и проектирование концертных залов. В этой работе Д.К. Миллер более двадцати лет применял фурье-анализ записанных самописцем звуковых колебаний [106-108] с помощью анализатора спектра Генрици, имел на эту тему ряд печатных работ [106-108]. Естественно, что он использовал этот свой опыт и для обработки результатов интерферометрических измерений [109] и показал, что периодическое изменение разности фаз в плечах вращающегося интерферометра Майкельсона происходит с удвоенной частотой вращения или, что то же самое, на второй гармонике частоты вращения [109]. Были также зарегистрированы более высокие гармоники: 3-я, 4-я и 5-я, но они были малы по сравнению со 2-й [109]. Сам Д.К. Миллер трактовал свои результаты [109] по регистрации второй гармоники частоты вращения интерферометра Майкельсона как подтверждение существования „светоносного эфира“, относительно которого движется Земля и, следовательно, интерферометр. Однако амплитуда изменения интерференционного сигнала на второй гармонике частоты вращения в [109] была существенно ниже, чем это ожидалось из теории „светоносного эфира“, что объяснялось Д.К. Миллером как следствие зависимости скорости „эфира“ от высоты над поверхностью Земли и движением Земли вместе с солнечной системой со скоростью $\sim 200 \mathrm{~km} / \mathrm{s}$ [109]. В работах [115-118] показано, что обнаруженный Д.К. Миллером эффект является следствием влияния гравитационного потенциала силы Кориолиса на разность фаз в плечах вращающегося интерферометра Майкельсона, который совершает также орбитальное движение вместе с Землей вокруг Солнца.

Механические анализаторы спектра были аналоговыми вычислительными устройствами и давно не применяются. В конце 40-х - начале 50-х гг. их сменили электронные спектроанализаторы - аналоговые устройства, в которых усиленный сигнал зависимости разности фаз в плечах интерферометра от времени пропускался через узкополосный электрический фильтр. Частота пропускания фильтра оставалась постоянной, а перестройке с помощью операции гетеродинирования подвергались частоты исследуемого сигнала. В 80-е гг. были созданы первые цифровые спектроанализаторы, которые в то время являлись специализированными малогабаритными компьютерами, проводившими цифровой фурье-анализ сигнала зависимости разности фаз в плечах интерферометра от времени. В настоящее время эта операция осуществляется персональными компьютерами, снабженными дополнительными специальными платами. В настоящее время применяется так называемый быстрый фурье-анализ [119].

\section{6. Упущенные возможности более раннего создания модуляционного метода измерения малой разности фаз}

В данном разделе мы покажем, что модуляционный метод измерения малой разности фаз вполне мог быть реализован на 20-30 лет раньше, чем это произошло в реальности, а также выясним причину такой досадной для оптики и метрологии задержки. Для реализации модуляционного метода необходимо выполнение трех условий: возможность модулировать длину плеча интерферометра по гармоническому закону, наличие достаточно чувствительного (с квантовой эффективностью минимум в десятки процентов) малоинерционного фотоприемника и малошумящего электронного усилителя.

Что касается первого условия, то возможность наклеивать одно из зеркал интерферометра на телефонный капсюль появилась уже в 1876 г. после создания А.Г. Беллом (1847-1922) телефонного аппарата.

Что касается третьего условия, то первая электронная радиолампа (так называемый аудион) была изготовлена 
Ли де Форестом (1873-1961) в 1906 г. [20], однако ее характеристики еще были невысоки. Непосредственно перед началом Первой мировой войны произошел значительный прогресс в улучшении характеристик радиоламп, и в 1914 г. уже имелись усилительные прямонакальные радиолампы - триоды - с уникальными шумовыми характеристиками: их эквивалентное шумовое сопротивление было всего порядка $10 \Omega$. Следует отметить, что прямонакальные радиолампы имели ряд существенных недостатков и, в частности, короткий срок службы и очень большой ток накала. Однако более совершенные усилительные ламповые триоды с косвенным оксидным накалом имеют эквивалентное шумовое сопротивление порядка $100-300 \Omega$ [121]. Созданные позднее ламповые пентоды с косвенным оксидным накалом имеют существенно большее усиление, но их эквивалентное шумовое сопротивление составляет порядка нескольких $\mathrm{k} \Omega$ [121]. Значительно лучшие характеристики имели прямонакальные ламповые триоды с покрытой тором нитью накала, которые стали выпускаться в начале 20-х гг. прошлого века. Их ток накала был примерно в 10 раз меньше, чем в обычных прямонакальных радиолампах, а эквивалентное шумовое сопротивление было невелико. Исследователи применяли различные ухищрения, чтобы снизить эквивалентное шумовое сопротивление радиоламп. Например, И.Л. Берштейн для первого каскада малошумящего усилителя заказывал 5-10 однотипных радиоламп и отбирал лампу с минимальным эквивалентным шумовым сопротивлением. Для первого каскада малошумящего усилителя также использовалось параллельное включение $N$ радиоламп [122], при этом эквивалентное шумовое сопротивление снижалось в $\sqrt{N}$ раз, причем иногда значение $N$ доходило до ста. При этом входная емкость системы из $N$ радиоламп увеличивалась в $N$ раз, что существенно ограничивало верхнюю частоту усиления.

Итак, в середине 10-х - начале 20-х гг. прошлого века для создания модуляционного метода измерения малой разности фаз требовался только высокочувствительный малоинерционный фотоприемник.

\section{Фотоприемники на внутреннем фотоэффекте}

В 1876 г. профессор физики (натурфилософии) Королевского колледжа (Лондон) В.К. Адамс (1836-1915) и его студент P.Е. Дэй обнаружили, что при облучении светом селена, нанесенного на платиновую подложку, возникает фотовольтаический эффект [123]. Селеновые фотоприемники фактически были первыми фотодиодами, но обладали малой чувствительностью и большой инерционностью. В разное время применялись другие типы фотоэлементов, например купроксные, но и они не имели достаточно высокой чувствительности и малой инерционности.

В 1922 г. О.Н. Лосев (1904-1942), сотрудник Нижегородской радиолаборатории (НРЛ) М.А. Бонч-Бруевича (1888-1940), в отделе В.К. Лебединского (1868-1937) изготовил на основе цинкита $(\mathrm{ZnO})$ светодиод и диод с падающим участком вольт-амперной характеристики, который мог работать в режиме усиления и генерации (так называемый кристадин) [124-126]. А в 1924 г. он обнаружил фотоэлектрический эффект при освещении карборундового кристалла $(\mathrm{SiC})$. Применяя свой метод шлифов, он показал, что этот эффект возникает в части активного слоя кристалла толщиной $1-3 \mu \mathrm{m}$ [124]. В 1927-1928 гг. им были исследованы на предмет фотоэффекта 92 вида полупроводниковых материалов, в том числе и кремний [126]. Фотодиоды О.Н. Лосева обладали высокой чувствительностью, но были недолговечны и нетехнологичны. К сожалению, довести свои полупроводниковые приборы хотя бы до полупромышленного уровня ему не довелось. В 1928 г. по решению правительства НРЛ была расформирована и вместе с сотрудниками передана в ленинградскую Центральную радиолабораторию (ЦРЛ) Треста заводов слаботочной электропромышленности. После преобразования в 1935 г. ЦРЛ в Институт радиовещательного приема и акустики тематика исследований резко сузилась. Лосеву работы по полупроводникам не нашлось, и ему пришлось уволиться. После этого он работал на кафедре физики Первого ленинградского медицинского института, умер в блокадном Ленинграде [124-126].

Промышленные образцы фотодиодов появились лишь в 50-х гг., но еще 10-15 лет они значительно уступали по чувствительности ФЭУ. Напомним, что проводившиеся в 1952 г. первые эксперименты с гармонической фазовой модуляцией в интерферометре Майкельсона проводились с ФЭУ [65].

\section{Фотоприемники на внешнем фотоэффекте}

В 1887 г. Г. Герц (1857-1994) впервые экспериментально обнаружил внешний фотоэффект для ультрафиолетовой области оптического спектра [127]. В тот период времени Г. Герц активно занимался исследованием обнаруженных им радиоволн [128] и более к вопросам внешнего фотоэффекта не возвращался. Следует отметить, что в 1888 г. В. Гальвакс (1859-1922) независимо от Г. Герца зарегистрировал внешний фотоэффект [129].

В 1888 г. крупнейший российский физик, действительный статский советник, заведующий кафедрой экспериментальной физики МГУ профессор А.Г. Столетов (1839-1896) подробно исследовал внешний фотоэффект и установил три закона Столетова, которые в современной терминологии формулируются следующим образом. 1. При фиксированной длине волны падающего света число фотоэлектронов, вырываемых из фотокатода в единицу времени, пропорционально интенсивности света (т. е. сила тока насыщения пропорциональна освещенности фотокатода).

2. Максимальная начальная скорость (максимальная начальная кинетическая энергия) фотоэлектронов не зависит от интенсивности падающего света, а определяется только его длиной волны. 
3. Для каждого вещества фотокатода существует красная граница фотоэффекта, т.е. максимальная длина волны света (зависящая от химической природы вещества фотокатода и состояния его поверхности), выше которой фотоэффект невозможен.

Отметим здесь, что существуют и другие формулировки законов А.Г. Столетова, в частности приведенные в учебном курсе Г.С. Ландсберга (1890-1957) [130].

А.Г. Столетов в высшей степени ответственно отнесся к своим новым результатам: он опубликовал в Докладах Французской (Парижской) АН четыре статьи [131-134], принесших ему мировую известность. Кроме того, он опубликовал в российском „Журнале Русского физикохимического общества“ весьма подробную статью [135], а также отпечатал в Санкт Петербурге отдельную брошюру [136] и статью во французском журнале по теоретической физике [137]. Однако А.Г. Столетов не смог продолжить свои исследования - вскоре он был втянут в достойный лишь сожаления затяжной конфликт с князем Б.Б. Голицыным (1862-1916) по поводу магистерской диссертации последнего [138], научным руководителем и одновременно оппонентом (рецензентом) которой он являлся. Разногласия соискателя и оппонента касались лишь 2-й части [138] „О лучистой энергии“, в которой понятие температуры распространяется на электромагнитное поле. По поводу значения 2-й части [138] в литературе существуют различные мнения: большинство авторов [139] считают ее прорывной, некоторые авторы указывают [140], что в то время физики были еще не в состоянии понять результаты Б.Б. Голицына, а сам он не сформулировал их достаточно ясно. Как бы то не было, А.Г. Столетов не допустил диссертацию [138] к защите, и Б.Б. Голицын был вынужден уволиться из МГУ. Это имело для А.Г. Столетова крайне тяжелые последствия: друг и покровитель Б.Б. Голицына, внук императора Николая I, президент Санкт-Петербургской академии наук великий князь К.К. Романов (1858-1915, литературный псевдоним К.Р.) отстранил кандидатуру А.Г. Столетова от избрания в Санкт-Петербургскую академию наук, а вместо него на позицию адьюнкта академии наук был избран Б.Б. Голицын [139,141]. От этого удара А.Г. Столетов так и не оправился и вскоре умер.

Если А.Г. Столетова интересовала научная сторона данного вопроса, установление физических законов фотоэффекта, то преподавателей Вольфенбюттельской гимназии (герцогство Брауншвейг, Германская империя) Ю. Эльстера (1854-1920) и Г. Гейтеля (1855-1923) - практическое применение внешнего фотоэффекта. В 1889 г. они изготовили фотоэлемент в стеклянном баллоне, наполненном газом низкого давления порядка $0.09-0.12 \mathrm{~mm} \mathrm{Hg}$ [142-144]. В период 1904-1905, 1907-1911 гг. их совместно семь раз номинировали на присуждение Нобелевской премии за исследование радиоактивности и фотоэффекта. В 1913 г. Ю. Эльстер и Г. Гейтель изготовили полупромышленный образец фотоэлемента в вакуумированном стеклянном баллоне [145], который вполне мог использоваться для экспериментов. Более совершенный фотоэлемент на внешнем фотоэффекте в вакуумированном стеклянном баллоне изготовил в 1914 г. Г. Айвс (1882-1953) [146]. Его работа о различных фотокатодах [147] была переведена на русский язык.

В дальнейшем Г. Айвс с соавтором, используя этот фотоэлемент, сумел экспериментально зарегистрировать предсказанный еще А. Эйнштеном [148] поперечный (квадратичный) эффект Допплера $[149,150]$ (см. также [151]).

В 1930 г. Л.А. Кубецкий (1906-1959) изобрел ФЭУ, в котором фототок из фотокатода многократно умножается за счет большого числа каскадов [152]. ФЭУ, который был изготовлен им в 1934 г., позволял регистрировать очень слабые потоки света [153] (см. также [154-156]).

В случае достаточно хорошей освещенности интерференционной картины модуляцию интенсивности интерференции можно точно измерить и без применения ФЭУ - с помощью фотоэлемента на внешнем фотоэффекте в вакуумированном стеклянном баллоне или с помощью фотодиода, фототок от которых усиливается малошумящим ламповым усилителем. Следовательно, модуляционный метод измерения малой разности фаз можно было реализовать еще в 1914 г. с помощью фотоэлемента на внешнем фотоэффекте или в 1923 г. с помощью фотодиода. В этом случае повторения экспериментов Майкельсона-Морли [39,40]: эксперименты Д.К. Миллера [97-101] (1921-1926 гг.), Р.Дж. Кеннеди [42] (1926 г.), К.К. Иллингворта [43] (1927г.) и А.А. Майкельсона и соавторов [102,103] (1929 г.), могли быть выполнены на существенно более высоком уровне точности, а метод ступенчатого зеркала $[42,43]$ вообще не понадобился бы.

К сожалению, об этой возможности тогда никто не задумался, поскольку профессиональные оптики привыкли к своим методам, а радиофизика, как наука, только начинала свое становление. Отметим, что еще в 1887 г. А.А. Майкельсон и Э. Морли в своей работе [40] рассматривали применение как телефона, так и селенового фотоэлемента, однако не для модуляции длины плеча интерферометра и регистрации модуляции величины фототока, а в ходе обсуждения возможности измерения однонаправленной скорости света и ее зависимости от направления распространения.

\section{Электрический и фотоэлектрический фурье-анализ}

Как отмечено в разд. 5, механические анализаторы спектра были сложными устройствами, требующими при работе больших усилий. Но уже в то время существовали методы, существенно упрощающие обработку интерференционного сигнала.

В 1894 г. М. Пупин (1858-1935, известный электрорадиоинженер, президент IRE - Института радиоинженеров США в 1917 г., о нем [157]) исследовал 
напряжение на выходе восьмиполюсной динамомашины, генерирующей переменный ток [Pupin1]. Для исследования спектрального состава напряжения он использовал колебательный контур с перестраиваемой резонансной частотой. М. Пупин обнаружил, что в напряжении помимо основной частоты присутствует большое число ее нечетных гармоник [158]. В частности, амплитуда 3-й гармоники составляла $1 / 9$ от амплитуды 1-й гармоники. Разумеется, в то время метод Пупина еще нельзя было использовать для гармонического анализа весьма слабых электрических сигналов с выхода фотоприемника, но после появления электронных радиоламп появилась возможность усиливать эти сигналы до необходимой величины и соответственно проводить методом [158] спектральный анализ зависимости изменения интерференционного сигнала от времени. Метод Пупина [158] является прообразом электронных спектроанализаторов и опередил их более, чем на 50 лет.

После конфликта со А.Г. Столетовым Б.Б. Голицын много лет занимался сейсмологией и, в частности, совместно с И. Вилипом (1870-1942) разработал и изготовил ряд лучших в мире сейсмографов [139], которые эксплуатировались еще более полувека. В 1913 г. Б.Б. Голицын предложил и реализовал фотоэлектрический метод гармонического анализа сейсмограмм [159]. Такая кривая в определенном масштабе переносилась на непрозрачную бумагу, которая разрезалась по кривой и накладывалась на прозрачный валик, который вращался и подсвечивался изнутри через узкую щель, после чего свет падал на селеновый элемент [159]. Напряжение с селенового элемента поступало на так называемый резонансный гальванометр, стрелка которого начинала значительно колебаться, когда частота напряжения совпадала с собственной частотой механических колебаний стрелки гальванометра. Таким образом, Б.Б. Голицын определял основную частоту сейсмических колебаний, а амплитуда этих колебаний определялась по амплитуде колебаний стрелки гальванометра. Если скорость вращения валика уменьшить в два раза, то можно измерить амплитуду второй гармоники сейсмограммы и т.д.

Метод Б.Б. Голицына можно было бы успешно применить для фурье-анализа в интерферометрии, в частности это мог бы сделать Д.К. Миллер в работе [109]. Но этого не случилось - Д.К. Миллер предпочел анализировать экспериментальную кривую зависимости интенсивности интерференции от угла поворота интерферометра Майкельсона [109] более сложным методом, с помощью анализатора Генрици (разд. 5). Методы М. Пупина и Б.Б. Голицына описаны в монографии [110].

Отметим здесь, что Б.Б. Голицын внес весьма существенный вклад в экспериментальное обоснование специальной теории относительности - совместно с И. Вилипом он доказал, что скорость света не зависит от скорости источника излучения [160-163] (см. также [164]).

\section{7. Заключение}

Модуляционный метод измерения малой разности фаз возник довольно неожиданно для специалистов по оптической интерферометрии. Показательным является следующий факт: в 1952 г. в одном и том же томе 47 журнала „Успехи физических наук“ были опубликованы два обзора известного советского оптика Г.В. Розенберга. Первый обзор в двух частях $[35,36]$ был посвящен многолучевой интерферометрии и занимал в общей сложности 132 журнальных страницы, а список цитируемой литературы включал 454 ссылки. Второй обзор, посвященный существенно более точной модуляционной интерферометрии [66], занимал всего 6 журнальных страниц, а список цитируемой литературы включал 7 ссылок.

Отметим, что со временем менялся и способ регистрации малой разности фаз. В середине XIX-начале $\mathrm{XX}$ веков сдвиг интерференционной картины наблюдали визуально, иногда использовали зрительную трубу для увеличения изображения. В начале $\mathrm{XX}$ века для регистрации интерференционной картины начали использовать фотопленку. Иногда применялся киноаппарат с покадровой съемкой для того, чтобы при вращении интерферометра Майкельсона каждому угловому положению интерферометра соответствовал свой кадр с некоторым шагом по углу вращения $[104,105]$. Позднее стали применять фотоприемники - ФЭУ или фотодиоды. Модуляционный метод измерения малой разности фаз может быть реализован только с помощью фотоприемника.

Перечислим основные результаты работы.

1. Первые оптические интерферометры создали крупнейшие оптики, „отцы физической оптики“, Т. Юнг и О. Френель.

2. Первые усовершенствования интерферометрических методов измерения весьма малых разностей фаз для регистрации различных физических явлений на первом этапе (1851-1925 гг.) осуществляли „отцы физической оптики“ И.А. Физо, А.А. Майкельсон, Э. Морли, лорд Рэлей и известные специалисты по интерферометрии Д.К. Миллер и Ж.М. Саньяк, а на втором этапе (1926-1950 гг.) - высококвалифицированные оптики.

3. Метод модуляционной интерферометрии был создан в период 1949-1952 гг. крупнейшими советскими радиофизиками А.А. Андроновым, И.Л. Берштейном и Г.С. Гореликом.

4. С.И. Вавилов активно интересовался развитием методов прецизионной интерферометрии. В 1926 г. он перевел на русский язык работу Р.Дж. Кеннеди о методе ступенчатого зеркала, а в 1949 г. наградил И.Л. Берштейна премией им. Л.И. Мандельштама в области физики за работу [60], позволившую реализовать метод модуляционной интерферометрии.

5. Метод модуляционной интерферометрии можно было реализовать еще в 1914 г. с помощью фотоэлемента на внешнем фотоэффекте (обнаруженном Г. Герцем и подробно исследованным А.Г. Столетовым) или в 1923 г. 
с помощью фотоэлемента на внутреннем фотоэффекте (фотодиоде, который был изготовлен О.Н. Лосевым). Однако тогда профессиональные оптики использовали традиционные методы измерения малой разности фаз, а радиофизика, как наука, только начинала свое становление.

6. Методы М. Пупина и Б.Б. Голицына (соответственно электрический и фотоэлектрический гармонический анализ) могли найти успешное применение в интерферометрии, но они намного опередили свое время и к тому моменту, когда могли найти практическое применение, были уже почти полностью забыты.

\section{Благодарности}

Автор выражает благодарность В.М. Геликонову за ряд полезных замечаний, позволивших существенно улучшить изложение результатов работы, Э.Г. Малыкину и В.И. Поздняковой за помощь в работе, М. Ефроимскому, Г.В. Колесниковой, Ф.Р. Тангерлини и П.А. Шилягину за помощь в изыскании труднодоступных литературных источников. Работа поддержана проектами по Государственному заданию № 0035-2019-0013.

\section{Конфликт интересов}

Автор заявляет, что у него нет конфликта интересов.

\section{Список литературы}

[1] Abbott B.P. et al. // Phys. Rev. Lett. 2016. V. 116. P. 061102.

[2] Берштейн И.Л. // ДАН СССР. 1950. Т. 75. № 5. С. 635.

[3] Michelson A.A. Studies in Optics. Chicago: The University of Chicago Press, 1927. Перевод: Майкельсон А.А. Исследования по оптике. М.-Л.: Гос. изд-во, 1928. 199 с., 2-е изд. М.: URSS, 2004. 200 с.

[4] Романова М.Ф. Интерференция света и ее применения. Л.-М.: ОНТИ, 1937. 176 с.

[5] Захарьевский А.Н. Интерферометры. М.: Гос. изд-во оборонной пром-ти, 1952. $296 \mathrm{c}$.

[6] Коломийцов Ю.В. Интерферометры. Основы инженерной теории, применение. Л.: Машиностроение. 1976. 296 c.

[7] Малыкин Г.Б., Позднякова В.И. Поляризационные эффекты в кольцевых интерферометрах. Нижний Новгород: ИПФ РАН, 2008. 208 c.

[8] Malykin G.B., Pozdnyakova V.I. Ring Interferometry. Berlin: De Gruyter, 2013. XVII+301 p.

[9] Малыкин Г.Б. // УФН. 2000. Т. 170. № 12. С. 1325.

[10] Андронова И.А., Малыкин Г.Б. // УФН. 2002. Т. 172. № 8. C. 849.

[11] Young T. Bakerian Lecture: Experiments and Calculations Relative to Physical Optics. Philosophical Transactions of the Royal Society. 1804. (read November 24 1803) V. 94. N 1-2.

[12] Fresnel A. Annales de chimie et de physique. Mars 1816. V. 1. Р. 239. Перевод: Френель О. Избранные труды по оптике. / Под ред. Ландсберг Г.С. М.: Гостехиздат, 1955. C. 103.
[13] Fizeau H. Comptes Rendus. 1851. V. 33. N 13. P. 349. Перевод: Физо И. Творцы физической оптики. Сб. статей. / Сост. Франкфурт У.И. М.: Наука, 1973. С. 214.

[14] Fresnel A. Annales de Chimie et de Physique. 1818. V. 9. P. 57. Перевод: Френель O. Письмо Огюстена Френеля к Франсуа Араго относительно влияния движения Земли на некоторые оптические явления // Избранные труды по оптике. / Под ред. Ландсберг Г.С. М.: Гостехиздат, 1955. C. 516.

[15] Sagnac M.G. // Compt. Rend. 1913. V. 157. N 17. P. 708.

[16] Sagnac M.G. // Compt. Rend. 1913. V. 157. N 25. P. 1410.

[17] Sagnac M.G. // J. Phys. (Paris). 1914. Ser. 5. V. 4. N 3. P. 177.

[18] Малыкин Г.Б. // УФН. 1997. Т. 167. № 3. С. 337.

[19] Малыкин Г.Б. // УФН. 2002. Т. 172. № 8. С. 969.

[20] Lord Rayleigh // Proc. Roy. Soc. (London). 1895-1896. V. 59. P. 198.

[21] Наргужин M.P. // Труды университета. Караганда: Карагандинский гос. техн. ун-т Мин-ва образования и науки Республики Казахстан, 2000. № 2. С. 13.

[22] Перминов А.В., Файзрахманова И.С. Прикладная голография. Курс лекций. Пермь: Пермский нац. иссл. ун-т, 2017. $89 \mathrm{c}$.

[23] Leith P.N., Upatnieks J. // JOSA. 1961. V. 51. N 7. P. 1469.

[24] Leith P.N., Upatnieks J. // JOSA. 1962. V. 52. N 10. P. 1123.

[25] Островский Ю.И., Бутусов М.М., Островская Г.В. Голографическая интерферометрия. М.: Наука, 1977. 336 с.

[26] Дуденкова В.В. Оптическая голография. Учебное пособие. Нижний Новгород: Нижегородский гос. ун-т им. Н.И. Лобачевского. Нац. иссл. ун-т. 2015. 56 с.

[27] Шимкин П.Е., Бабокин М.И., Баскаков А.И. // Современные проблемы дистанционного зондирования Земли из космоса. 2017. Т. 14. № 5. С. 103.

[28] Howell S.K. The Development and Use of the Rayleigh Interferometer to Study Molecular Diffusion in an Applied Magnetic Field. Ph.D. Thesis. Canada, Vancouver: University of British Columbia, 1983. 177 p.

[29] Hunzinger J.J. // Rev. d'Optique. 1957. V. 36. N 6. P. 285.

[30] Zernike F. // J. Opt. Soc. Am. 1950. V. 40. N 5. P. 326.

[31] Bottema M., Zernike F.J. // Opt. Soc. Am. 1951. V. 41. N 11. P. 870.

[32] Юрьев В. // УФН. 1952. Т. 47. № 1. С. 146.

[33] Hariharan P., Sen D. // JOSA. 1959. V. 49. N 3. P. 232.

[34] Hariharan P., Sen D. // JOSA. 1960. V. 50. N 4. P. 357.

[35] Розенберг Г.В. // УФН. 1952. Т. 47. № 1. С. 3.

[36] Розенберг Г.В. // УФН. 1952. Т. 47. № 2. С. 173.

[37] Кулеш В.П. // Автометрия. 1987. № 2. С. 34.

[38] Michelson A.A., Gale H.G. Assisted by Pearson F. // Astrophys. J. 1925. V. 61. N 5. Р. 140. Перевод: Майкельсон $А$., Гель Г. при участии Ф. Пирсона. Эфирный ветер. Сб. статей. / Под ред. Ацюковский В.А.. М.: Энергоатомиздат, 2011. С. 77.

[39] Michelson A.A. // Am. J. Sci. 1881. Ser. III. V. 22. N 128. P. 120.

[40] Michelson A.A., Morley E.W. // Am. J. Sci. 1887. Ser. III. V. 34. N 203. Р. 333. Перевод: Майкельсон А.А., Морли Э.В. Эфирный ветер. Сб. статей. / Сост. Ацюковский В.А. М.: Энергоатомиздат, 2011. C. 41.

[41] Morley E.W., Miller D.C. // Phil. Mag. 1905. Ser. 6. V. 9. N 53. Р. 680. Перевод: Морли Э., Миллер Д. Эфирный ветер. Сб. статей. / Под ред. Ацюковский В.А.. М.: Энергоатомиздат, 2011. С. 62. 
[42] Kennedy R.J. // Proc. Natl. Acad. Sci. U.S. 1926. V. 12. N 11. Р. 621. Перевод: Кеннеди Р. Джс. Эфирный ветер. Сб. статей. / Под ред. Ацюковский В.А.. М.: Энергоатомиздат, 2011. C. 137.

[43] Illingworth K.K. // Phys. Rev. 1927. V. 30. N 5. P. 692. Перевод: Иллингворт К.К. Эфирный ветер. Сб. статей. / Под ред. Ацюковский В.А.. М.: Энергоатомиздат, 2011. C. 148.

[44] Вавилов С.И. // УФН. 1926. Т. 6. № 4-5. С. 421.

[45] Вавилов С.И. Экспериментальные основания теории относительности. Сер. Новые течения научной мысли. № 3-4. М.-Л.: Госиздат, 1928. Вавилов С.И. Собр. соч. М.: Изд. АН СССР, 1956. Т. 4. С. 9.

[46] Thomas H.A., Warren G.W. // Philos. Mag. 1928. Ser. 7. V. 5. N 32. P. 1125.

[47] Paasch P. // Zeitschrift für Technical Physik. 1928. V. 9. N 10. P. 411.

[48] Вернер А.А., Жабин А.С. // Оптико-механическая промышленность. 1937. Т. 7. № 5. С. 3.

[49] Островская Г.В. // ЖТФ. 2016. Т. 86. № 6. С. 1.

[50] Алексеенко И.В., Гусев М.Е., Педрини Д. // Вестник РГУ им. И. Канта. 2004. В. 4. Физ.-мат. науки. С. 45.

[51] Болотовский Б.М., Малыкин Г Б. // УФН. 2019. Т. 189. № 10. C. 1084.

[52] Abramson N. // Opt. Lett. 1978. V. 3. N 4. P. 121.

[53] Abramson N. // Appl. Opt. 1983. V. 22. N 2. P. 215.

[54] Abramson N. // Appl. Opt. 1984. V. 23. N 10. P. 1481.

[55] Abramson N. // Appl. Opt. 1984. V. 23. N 22. P. 4007.

[56] Abramson N. // Appl. Opt. 1985. V. 24. N 20. P. 3323.

[57] Dicke R.H // Rev. Sci. Instr. 1946. V. 17. N 7. P. 268.

[58] Бунимович В.И. // ЖТФ. 1950. Т. 20. N 8. С. 944.

[59] Малыкин Г.Б. И.Л. Берштейн - научная деятельность. К 90-летию со дня рождения. Н. Новгород: ИПФ РАН, 1998. $20 \mathrm{c}$.

[60] Беритейн И.Л. // Изв. АН СССР. Сер. Физ. 1950. Т. 14. № 2. С. 145.

[61] Берштейн И.Л. Флуктуации в автоколебательных системах. Дис. канд. физ.-мат. наук. Горький, 1939. 114 с.

[62] Кисляков А.Г., Разин В.А., Троицкий В.С., Цейтлин Н.М. Радиоастрономические исследования в Горьком. Препринт НИРФИ N 163. Горький, 1983. 48 с.

[63] Берштейн И.Л. Исследование весьма малых изменений разности фаз в радио и оптике. Дис. докт. физ.-мат. наук. Горький, 1953. 191 с.

[64] Горелик Г.С. // ДАН СССР. 1952. Т. 83. № 4. С. 553.

[65] Брусин И.Я., Горелик Г.С., Пиковский С.А. // ДАН СССР. 1952. T. 83. № 4. С. 549.

[66] Розенберг Г.В. // УФН. 1952. Т.47. № 4. С. 631.

[67] Берштейн И.Л. // УФН. 1953. Т. 49. Вып. 4. С. 631.

[68] Берштейн И.Л. // ДАН СССР. 1954. Т. 94. № 4. С. 655.

[69] Берштейн И.Л. Сборник памяти А. Андронова. М.: Изд. AH CCCP, 1955. С. 577.

[70] Горелик Г.С. Колебания и волны. М.-Л.: ГИИТЛ, 1950. $552 \mathrm{c}$.

[71] Касьян А.А., Понамарев С.М. // ВИЕТ. 2001. № 1. С. 97.

[72] Рытов С.М. // УФН. 1957. Т. 62. Вып. 4. С. 485.

[73] Зайщев Ю.И., Степанов Д.П. // Письма в ЖЭТФ. 1967. Т. 6. Вып. 7. С. 733.

[74] Зайщев Ю.И., Степанов Д.П. // ЖЭТФ. 1968. Т. 55. Вып. 5. С. 1645.

[75] Геликонов В.М., Малыкин Г.Б. // Квант. электрон. 1983. T. 10. № 1. C. 145.
[76] Летохов В.С. // Письма в ЖЭТФ. 1967. Т. 6. Вып. 4. C. 597.

[77] Геликонов В.М. // Изв. вузов. Радиофизика. 1998. Т. 41. № 11. C. 1473.

[78] Берштейн И.Л., Геликонов В.М., Степанов Д.П. // Изв. вузов. Радиофизика. 1998. Т. 41. № 11. С. 1461.

[79] Алексеев Э.И., Базаров Е.Н., Израелян В.Г., Сверчков Е.И., Телегин Г.И. // Письма в ЖТФ. 1979. Т. 5. Вып. 17. С. 1050.

[80] Ulrich R. // Opt. Lett. 1980. V. 5. N 5. P. 173.

[81] Bergh R.A., Lefevre H.C., Shaw H.J. // Opt. Lett. 1981. V. 6. N 10. P. 502.

[82] Kim B.Y., Lefevre H.C., Bergh R.A., Shaw H.J. // Proc. SPIE. 1983. V. 425. P. 86.

[83] Малыкин Г.Б. // Изв. вузов. Радиофизика. 1994. Т. 37. № 10. C. 1345.

[84] Малыкин Г.Б. // Изв. вузов. Радиофизика. 1996. Т. 39. № 5. C. 624.

[85] Малыкин Г.Б., Малыкин Э.Г. // Опт. и спектр. 2008. T. 105. № 1. C. 128.

[86] Малыкин Г.Б. // Изв. вузов. Радиофизика. 1992. Т. 35. № 1. C. 98.

[87] Малыкин Г.Б. // Изв. вузов. Радиофизика. 1995. Т. 38. № 6. C. 604.

[88] Пьезокерамические преобразователи. Справочник. / Под ред. Пугачева С.И. Л.: Судостроение, 1984. 256 с.

[89] Амбариумян C.A. Разномодульная теория упругости. М.: Наука, 1982. $320 \mathrm{c}$.

[90] Жуков А.М. // ПМТФ. 1985. № 4(152). С. 128.

[91] Островский Л.А. // Акустический журнал. 1988. Т. 34. Вып. 5. С. 908.

[92] Беляева И.Ю., Зайцев В.Ю., Тиманин Е.М. // Акустический журнал. 1994. Т. 40. № 6. С. 893.

[93] Зайщев В.Ю. // Акустический журнал. 1995. Т. 41. № 3. C. 439.

[94] Малыкин Г.Б., Розенталь А.Е. // Изв. вузов. Радиофизика. 1999. Т. 42. № 2. С. 198.

[95] Kim D.Y., Shaw H.J. // Opt. Lett. 1984. V. 9. N 8. P. 375.

[96] Toyama K., Fesler K.A., Kim B.Y., Shaw H.J. // Opt. Lett. 1991. V. 16. N 15. P. 1207.

[97] Miller D.C. // Phys. Rev. 1922. V. 19. N 4. P. 407.

[98] Miller D.C. // Science. 1922. V. 55. N 1427. P. 486.

[99] Miller D.C. // Proc. Natl. Acad. Sci. U.S. 1925. V. 11. N 6. Р. 306; Миллер Д.К. // УФН. 1925. Т. 5. Вып. 3. С. 177.

[100] Miller D.C. // Nature. 1925. V. 116. N 2906. P. 49; Миллер Д.К. // ПЗМ. 1925. № 8-9. С. 194.

[101] Miller D.C. // Science. 1926. V. 43, N 1635. P. 433; Миллер Д.К. // ПЗМ. 1926. № 11. С. 91.

[102] Michelson A.A., Pease F.G., Pearson F. // Nature. 1929. V. 123. N 3090. P. 88.

[103] Michelson A.A., Pease F.G., Pearson F. // JOSA. 1929. V. 18. N 3. P. 181.

[104] Piccard A., Stahel E. // Comptes Rendus. 1927. V. 185. N 22. P. 1198.

[105] Joos G. // Ann. der Phys. 1930. Ser. 5. V. 7. N 4. P. 385.

[106] Shankland R.S. // Am. J. Physics. 1941. V. 9. N 5. P. 273.

[107] Fletcher H. Dayton Clarence Miller. 1866-1941. Nat. Acad. of Sciences of the USA. // Biographical Memoirs. 1943. V. 23. P. 59.

[108] Fickinger H. Miller's Waves An Informal Scientific Biography. Department of Physics Case Western Reserve University, 2011. 127 p. 
[109] Miller D.C. // Rev. Mod. Phys. 1933. V. 5. N 3. P. 203; Миллер Д.К. // Эфирный ветер. Сб. статей. / Сост. Ацюковский В.А. М.: Энергоатомиздат, 2011. С. 237.

[110] Meyer Zur Kapellen W. Mathematische Instrumente. Leipzig, 1944; Мейер Цур Капеллен В. Математические инструменты. 2-е изд. М.: ИЛ, 1950. 316 с.

[111] Henrici $O$. // The London, Edinburgh, and Dublin Philosophical Magazine and Journal of Science. 1894. V. 38. P. 110.

[112] Kennelly A.E. Samuel Wesley Stratton. 1861-1931. Nat. Acad. of Sciences of the USA. // Biographical memoirs. 1935. V. 17. P. 251.

[113] Michelson A.A., Stratton S.W. // Phil. Mag. 1898. Ser. 5. V. 45. N 3. P. 85.

[114] Michelson A.A. Light Waves and Their Uses. Chicago: The University of Chicago Press, 1903. 171 p.; Михельсон A.A. Световые волны и их применение. М.-Л.: Гостехидат, 1934. $143 \mathrm{c}$.

[115] Малыкин Г.Б., Позднякова В.И. // УФН. 2015. Т. 185. № 4. C. 431.

[116] Малыкин Г.Б., Позднякова В.И. // УФН. 2015. Т. 185. № 8. C. 895.

[117] Малыкин Г.Б., Позднякова В.И. // УФН. 2016. Т. 186. № 7. C. 796.

[118] Малыкин Г.Б., Позднякова В.И. // Опт. и спектр. 2016. T. 121. № 6. C. 977.

[119] Nussbaumer H.J. Fast Fourier Transform and Convolution. Second Corrected and Updated Edition. Springer Series in Information Sciences; Нуссбаумер Г. Быстрое преобразование Фурье и алгоритмы вычисления сверток. М.: Радио и связь, 1985. 248 с.

[120] De Forest L. // Proc. IRE. 1914. V. 2. P. 15.

[121] Торопкин М.B. Ламповый Hi-Fi усилитель своими руками. СПб.: Наука и техника, 2005. 240 с.

[122] Handbook of Tube Operation - USA. New Ark. New Jersey: Federal Telephone and Radio Corporation, 1944. 2-d edition. P. 19.

[123] Adams W.G., Day R.E. // Proc. Roy. Soc. London. 1877. V. 25. N 171-178. P. 113.

[124] Новиков М.A. // ФТТ. 2004. Т. 45. № 1. С. 5.

[125] Носов Ю.Р. // Химия и жизнь. 2004. № 2. С. 42.

[126] Григорьев Н.Д. // Мир транспорта. 2012. С. 186.

[127] Hertz H.R. // Annalen der Physik Physik und Chemie. 1887. Ser. III. V. 31. N 8. P. 983.

[128] Hertz H.R. // Annalen der Physik Physik und Chemie. 1887. Ser. III. V. 31. N 7. P. 421.

[129] Hallwachs W. // Annalen der Physik Physik und Chemie. 1888. Ser. III. V. 33. N 2. P. 302.

[130] Ландсберг Г.С. Оптика. М.: Наука, 1976. 928 с.

[131] Stoletow A. // Comptes Rendus. 1888. V. 106. N 16. P. 1149.

[132] Stoletow A. // Comptes Rendus. 1888. V. 106. N 23. P. 1593.

[133] Stoletow A. // Comptes Rendus. 1888. V. 107. N 2. P. 91.

[134] Stoletow A. // Comptes Rendus. 1889. V. 108. N 24. P. 1241.

[135] Столетов А.Г. // ЖРФХО. Часть физическая. 1889. Т. 21. Вып. 7-8. С. 159.

[136] Столетов А.Г. Актино-электрическія изслдованія. СПб.: 1889. Тип-я В. Демакова, 48 с.

[137] Stoletow A. // J. Phys. Theor. Appl. 1890. V. 9. N 1. P. 468.

[138] Голицын Б.Б. Исследование по математической физике. Магистерская диссертация. М.: МГУ. 1893. // Голицын Б.Б. Избр. труды. Т. 1. Физика. М.: Изд-во АН СССР, 1960. C. 73.
[139] Предводителев А.С. О физических работах Б.Б. Голицына. Голицын Б.Б. Избранные труды. Т. 1. Физика. М: Изд-во АН СССР, 1960. С. 218.

[140] Вдовиченко Н.В. Развитие фундаментальных принципов статистической физики в первой половине XX века. М.: Наука, 1986. 160 с.

[141] Булюбаш Б.В., Голицын Б.Б. // Природа. 2016. № 7. С. 69.

[142] Elster J., Geitel H. // Annalen der Physik und Chemie. 1889. Ser. III. V. 38. N 9. P. 27.

[143] Elster J., Geitel H. // Annalen der Physik und Chemie. 1889. Ser. III. V. 38. N 9. P. 40.

[144] Elster J., Geitel H. // Annalen der Physik und Chemie. 1889. Ser. III. V. 38. N 12. P. 497.

[145] Elster J., Geitel H. // Physikalische Zeitschrift. 1913. V. 14. P. 741.

[146] Ives H.E. // Astrophys. J. 1914. V. 39. P. 428.

[147] Ives H.E., Fry T.C. // JOSA. 1933. V. 23. N 3. P. 74; Ивес Г.Е, Фрай Т.К. УФН. 1934. Т. 14. № 1. С. 104.

[148] Einstein A. // Ann. der Phys. 1905. V. 17. N 10. P. 891; Эйнштейн А. Собр. соч. М.: Наука. 1965. Т. 1. С. 7.

[149] Ives H.E., Stilwell G.R. // JOSA. 1938. V. 28. N 7. P. 215.

[150] Ives H.E., Stilwell G.R. // JOSA. 1941. V. 31. N 5. P. 369.

[151] Малыкин Г.Б. // Опт. и спектр. 2009. Т. 107. № 4. С. 624.

[152] it Кубецкий Л.А. Устройство для усиления слабых токов. АС 74242 от 4 авг. 1930. Свид. № 45765 опубл. 31.01.1936.

[153] Кубецкий Л.А. // Автоматика и телемеханика. 1936. № 1. C. 17.

[154] Лукьянов С.Ю. Фотоэлементы. М.-Л.: Изд-во АН СССР, 1948. $371 \mathrm{c}$

[155] Чечик Н.О. // УФН. 1949. Т. 37. № 1. С. 74.

[156] Соболева Н.А., Берковский А.Г., Чечик Н.О., Елисеев P.E. Фотоэлектроные приборы. М.: Наука, 1965. 592 с.

[157] Davis B. Michael Idvorsky Pupin. 1858-1935. Nat. Acad. of Sciences of the USA. // Biographical memoirs. 1938. V. 19. P. 305.

[158] Pupin M.I. // Am. J. Sci. 1894. Ser. III. V. 48. N 28. P. 379.

[159] Von Furst B. Galitzin (Golicyn) // Известия Императорской академии наук. Санкт-Петербург, 1913. Серия 6. Т. 7. Вып. 9. С. 449.

[160] Prince Golitzin B., Wilip J. // Записки АН по физ.-мат. отд. 1906. T. 17. N 6. C. 1.

[161] Prince Golitzin B., Wilip J. // Записки АН по физ.-мат. отд. 1907. T. 19. N 9. C. 1.

[162] Prince Golitzin B., Wilip J. // Astrophys. J. 1907. V. 13. P. 15.

[163] Prince Golitzin B., Wilip J. // Записки АН по физ.-мат. отд. 1909. T. 22. N 1. C. 1.

[164] Малыкин Г.Б. // Опт. и спектр. 2010. Т. 109. № 6. С. 1018. 